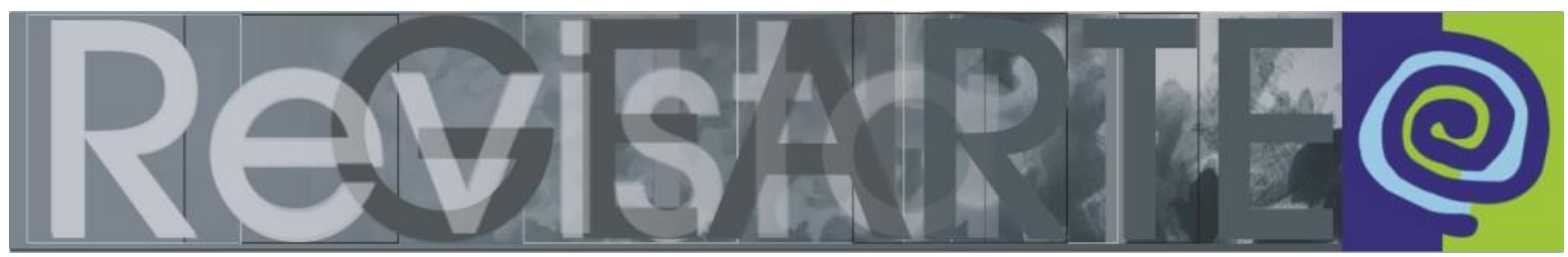

ISSN 2357-9854

\title{
Anacronismo, corpo e memória nas imagens escatológicas de Francisco Toledo
}

\author{
Vanessa Daniele Moraes (Universidade de Brasília - UnB, Brasília/ DF, Brasil)
}

\begin{abstract}
RESUMO - Anacronismo, corpo e memória nas imagens escatológicas de Francisco Toledo A ideia de que os fluidos do nosso corpo devem provocar nojo e repugnância atravessa séculos e tem explicações históricas, das quais buscamos alguns pensadores (Georges Vigarello e Mikhail Bakhtin) para elucidar as razões que solidificaram um imaginário do corpo sujo. Nas artes visuais, o artista mexicano Francisco Toledo (1940) desconstrói a noção do excremento como um dejeto que deve causar repúdio nas pessoas. Sua obra pode ser lida num duplo contato com o corpo: quando ele usa a merda como tema (dejeto corporal) e quando pensamos em suas pinturas pelo viés antropológico, onde as imagens têm um significado simbólico e são, literalmente, formadas no corpo humano. A carga afetiva e emocional que envolvem a formação das imagens no homem contribui para que a imaginação seja única, intransponível e anacrônica.
\end{abstract}

PALAVRAS-CHAVE

Memória. Escatologia. Francisco Toledo. Corpo.

RESUMEN - Anacronismo, el cuerpo y la memoria en imágenes escatológicas de Francisco Toledo - La idea de que los fluidos de nuestro cuerpo deben provocar asco y repugnancia atraviesa siglos y tiene explicaciones históricas, de las cuales buscamos algunos pensadores (Georges Vigarello y Mikhail Bakhtin) para elucidar las razones que solidificaron un imaginario del cuerpo sucio. En las artes visuales el artista mexicano Francisco Toledo (1940) desmonta la noción del excremento como un desecho que debe causar repudio en las personas. Su obra puede ser leída en un duplo contacto con el cuerpo: cuando él utiliza la mierda como tema (desecho corporal) y cuando pensamos en sus pinturas por la vía antropológica, donde las imágenes tienen un significado simbólico y son, literalmente, formadas en el cuerpo humano. La carga afectiva y emocional que encierran la formación de las imágenes en el hombre contribuye para que la imaginación sea única, insuperable y anacrónica.

PALABRAS CLAVE

Memoria. Escatología. Francisco Toledo. Cuerpo.

Toda excreção fisiológica tende a ser concebida como algo nojento e distante de uma "boa" higiene. O que sai de nosso corpo é percebido como imundo e, isso nos leva a pensar que estamos nos distanciando cada dia mais daquilo que é natural (e que, outrora, fora visto com naturalidade). Não é de se surpreender que as indústrias dos cosméticos queiram nos convencer de que temos um corpo sujo e que precisamos nos perfumar. Tornam-se abjetos as fezes, a urina, o sangue menstrual, o suor, o sêmen, e o leite materno, que hoje cede espaço para as mamadeiras. Podemos pensar que, até mesmo, um dejeto considerado "limpo", como a lágrima, tem seu 
banimento social: o adulto se envergonha de chorar em público'1. O sujeito deve manter a ordem, deve prezar pela introspecção, pelo ocultamento das práticas que ejetam algo de seu corpo. Deve ter vergonha de fazer suas "necessidades" fora de casa, de chorar perto de outras pessoas (sobretudo se for homem), de suar. O suor indica um trabalho mais pesado que se contrapõe ao trabalho mental (mais bem aceito a partir da modernidade). Um operário que trabalha em pé - sua, fica sob o sol, com calor, caminha, faz força física durante seu ofício — tem menos prestígio socialmente do que aquele que trabalha sentado em seu escritório no aconchego do ar condicionado (BAITELLO JR, 2012).

Se fizermos, ainda, uma relação dos cheiros corporais com determinadas classes sociais, notaremos que o senso comum atribui uma ligação de "boa higiene" às classes mais privilegiadas. Esse dado tem explicações históricas: Georges Vigarello, em $O$ limpo e o sujo, trata da cultura dos banhos na Europa (mais especificamente na Itália, Espanha e França) na Idade Média e indica que a higiene do corpo está arraigada, no terreno social, através dos costumes e de uma preocupação com a aparência exterior. Mostrar-se limpo pelas vestimentas dava muito mais status do que lavar as partes íntimas. Além disso, o costume da brancura da roupa se reforçou com a chegada da peste negra em Barcelona em 1546 e com a crença de que a água infiltrada no corpo pela porosidade da pele poderia transmitir doenças. Assim, houve um tempo de medo e reclusão: nada de saunas (muito em voga na época), de banhos, de convivência em lugares cheios de pessoas como igrejas ou escolas. Os banhos eram tomados em muitos casos só quando a criança atingisse sete anos, e assim ficavam por mais tantos outros anos isentos dessa prática. A limpeza corporal era feita através de panos úmidos, priorizando rosto e mãos (partes externas e visíveis ao outro). Quanto mais brancura na roupa, mais concreta era a ideia de que aquela pessoa era asseada e limpa.

A quantidade de roupas para as trocas influenciava, então, na polidez e na "civilidade", já que, tendo mais peças, menor a possibilidade de usar uma roupa

1 Georges Didi-Huberman, em Que emoção? Que emoção! destaca que o choro é uma manifestação emotiva que vem sendo coibida ao longo do crescimento do homem - a criança chora como forma de se comunicar, de expressar sentimentos; já o adulto tende a esconder seu choro, a ocultar seu sentimento de tristeza e insatisfação. 
"encardida". E a perpetuação dessa limpeza pela roupa se estende para as classes privilegiadas, uma vez que as condições das indumentárias são melhores. Vigarello traz um relato de um estudante pobre do século XV que se vê cheio de parasitas pelo corpo e numa "odisseia" pra se livrar deles: "A atenção centra-se nos invólucros da pele. [...] A sua 'nudez' é apenas uma nudez social” (VIGARELLO, 1985, p. 41). De modo semelhante temos a prostituição associada a um mau cheiro - a palavra "puta" deriva de puer (feder) —, reforçando um imaginário de que as classes economicamente privilegiadas são também detentoras de um poder social que passa pelos cheiros das pessoas.

Por outro lado, as paródias medievais conseguiam atribuir um caráter cósmico às questões do corpo, de modo que a topografia céu-terra pudesse ser relacionada com regiões corporais - no caso, cabeça-baixo ventre. O imundo, no corpo, então se ligava às imundícies terrenas e, concomitantemente, ao coito, prática que gera vida. Rebaixamento sim, mas também um início. É isso o que nos conta Mikhail Bakhtin (2008), em seu estudo minucioso sobre a obra de François Rabelais, A cultura popular na Idade Média e no Renascimento. Ele revela que no realismo grotesco (sistema de imagens da cultura cômica popular), o "cósmico, o social e o corporal estão ligados indissoluvelmente numa totalidade viva e indivisível" (2008, p. 17). Ao analisar o contexto rabelaisiano, Bakhtin assegura a diferença das paródias medievais com as modernas literárias, que também degradam, mas sempre num sentido negativo. As medievais têm sentidos ambivalentes, regeneradoras. Para o realismo grotesco, rebaixar

[...] consiste em aproximar da terra, entrar em comunhão com a terra concebida como um princípio de absorção e, ao mesmo tempo, de nascimento: quando se degrada, amortalha-se e semeia-se simultaneamente, mata-se e dá-se a vida em seguida, mais e melhor.

Degradar significa entrar em comunhão com a vida da parte inferior do corpo, a do ventre e dos órgãos genitais, e portanto com atos como o coito, a concepção, a gravidez, o parto, a absorção de alimentos e a satisfação das necessidades naturais. A degradação cava o túmulo corporal para dar lugar a um novo nascimento. $E$ por isso não tem somente um valor destrutivo, negativo, mas também positivo, regenerador: é ambivalente, ao mesmo tempo negação e afirmação (BAKHTIN, 2008, p. 19).

Nos tempos atuais, o mau cheiro, o desagradável, o intolerável e o abjeto estão relacionados com a questão de gosto, de mau gosto, de desgosto. Os artistas, os 
poetas e pesquisadores são os que experimentam esse impulso de "tocar" no abjeto, pois possuem "espíritos impacientes" e o estado afetivo está sempre sobressaindo. Assim, o centro do desgosto se desloca mais para o sentir (toca o estômago mais do que o cérebro) do que para a consciência. $O$ desgosto se liga aos artistas, homens que produzem através da sensibilidade e, não aos grandes conhecedores de uma racionalidade lógica (PERNIOLA, 2010, p. 21).

É a partir das contribuições de artistas que pretendemos pensar sobre o corpo e os dejetos corporais. Buscaremos uma compreensão das imagens do excremento a partir de pontos de vista que não se reduzam ao repugnante. Será que essas imagens não podem também suscitar outras imagens, outras recordações? A busca por artistas considerados "ousados" por adentrar nesse terreno das fezes, do sangue menstrual, das vísceras pode ajudar na reflexão das imagens do corpo e dos seus dejetos. Para isso, elegemos um artista mexicano que transita pelo campo da abjeção em suas obras - Francisco Toledo (1940). Dentre outros que poderiam enriquecer a pesquisa com a vertente abjeta na arte (como por exemplo, o brasileiro Artur Barrio, o espanhol Nono Bandera, ou a australiana Casey Jenkins), conseguimos perceber a potência anacrônica suscitada nas obras de Toledo, já que elas estabelecem relações entre diferentes tempos históricos, não separando as fronteiras entre passado, presente e futuro de forma linear. Em suas imagens, as referências ao passado promovem uma sincronia com o presente por meio da memória. Veremos que há aberturas e descontinuidades temporais que recusam o historicismo tradicional - aqui os mitos ou uma tela de Francisco Toledo podem trazer à tona narrativas que se conectam por associações mnemônicas através do corpo. O corpo será visto como meio, como acesso à comunicação e transmissão dessas imagens.

Francisco Toledo nasceu em Juchitán — México, mas vive em Oaxaca - capital do estado homônimo - e ainda contribui para a preservação do patrimônio cultural oaxaquenho. Ele é pintor, gravurista, ceramista e, eventualmente, faz trabalhos na área da fotografia. Em visita ao México e conversando com professores de Estética ou galeristas, percebemos que o artista é muito estudado por seu ativismo político. Pretendemos ir por um outro caminho: Toledo como artista tem muito a acrescentar nessa pesquisa sobre o corpo e seus fluidos. A obra de Toledo é vasta para a 
pesquisa, sobretudo se quisermos adentrar na área da animalidade. O que interessa, nesse momento, são imagens dos "cadernos de merda". Tais cadernos são repletos de desenhos que o artista produziu durante sua estadia na França entre 1985 e 1987 nas noites de insônia. Além desses, Toledo fez outros tantos: de gatos, de insone, chino, dos insetos. la numerando cada um dos seus trabalhos. Somente os "de merda" contabilizam 27. Os cadernos foram usados como forma de pagamento de impostos para a Secretaria da Fazenda, correspondente ao ano 2000, num programa de governo chamado "Pago en especie". Por serem peças únicas entregues à instituição e não haverem reproduções desses cadernos, consultamos uma publicação intitulada Los cuadernos de mierda, de 2001, que reúne várias imagens diversificadas desses cadernos todos (não só os de merda) ${ }^{2}$.

David Huerta, no catálogo de exposição Los cuadernos insomnes de Francisco Toledo (1993) destaca três elementos orgânicos na obra do juchiteco: a animalidade, a sexualidade e a merda. A respeito deste último, Huerta assinala que há um jogo enérgico de afirmações e ironias, onde a merda aparece como anterior a tudo no universo. Além disso, há uma dicotomia relativa à merda que é fundamental: ela é o elemento descartável e excludente, da nossa vida; mas é também necessária. Talvez isso nos inquiete e nos assombre tanto, como explica Huerta:

[...] ingrediente de la feracidad fisiológica que arma su teatro de desperdicios con la Necesidad de la vida misma, la mierda literalmente circula de dentro a afuera en estos dibujos y los enmarca, los tacha, los mancha y los exorna, los desfigura y los edifica, los define y los perturba. ¿O es a nosotros, a los espectadores, a quienes los vemos llenos de asombro, a quienes nos hace todo eso la mierda de estos dibujos, tema y provocación incesante?

Na continuidade do orgânico, as fezes se juntam à terra. As cores são ocres, marrons. No Cuaderno de mierda 2, a morte, que também remete à organicidade do corpo, deixa seu excremento sobre a terra. Na imagem em questão, o corpo já se decompôs, restaram os ossos, o esqueleto. Mas a própria merda contrapõe como elemento vivo, que pode fecundar o solo, como bem lembrou Huerta (1993, p. 14), "semejante a una voluminosa semilla que producirá las cosechas". Há, na pintura, de

2 A edição está esgotada, mas consultamos um exemplar no Instituto de Artes Gráficas de Oaxaca (IAGO) em 10 de outubro de 2016. 
acordo com Verónica Volkow (2015, p.63), há uma grande ambição em ultrapassar as superfícies, de aprofundar mais além do visível e avançar nos

[...] espacios imaginarios mentales, retraídos de la experiencia real. Las revelaciones de lo interior, de las que lo visual ha querido afanosamente apropiarse, han tomado la más de las veces cuerpo de imágenes.

Mas de que maneira essas imagens são formadas e como elas adquirem força imaginativa?

Podemos pensar que a obra de Francisco Toledo perpassa duplamente pelo corpo ao considerarmos que ele usa como tema a merda (o de dentro e o de fora as fronteiras do corpo, a sexualidade) e quando analisamos suas imagens pelo viés antropológico. Em Antropologia das imagens, Hans Belting (2014) convida-nos a problematizar questões do meio, da imaginação e do corpo. Com ele, podemos perceber que as imagens têm significado simbólico e passam, literalmente, por dentro de nós. Sua abordagem antropológica significa que o enfoque será prioritariamente o homem - as imagens precisam do corpo para tomar forma. Belting explicita assim essa inter-relação:

Os homens isolam dentro de sua actividade[sic] visual, que constitui a sua lei vital, aquela unidade simbólica que chamamos "imagem". O duplo sentido de imagens internas e externas não se há-de separar pois do conceito de imagem e atraiçoa precisamente a sua fundamentação antropológica. Uma "imagem" é mais do que um produto da percepção. Surge como o resultado de uma simbolização pessoal ou coletiva. Tudo o que comparece ao olhar ou perante o olho interior pode deste modo aclarar-se através da imagem ou transformar-se numa imagem (BELTING, 2014, p. 21).

Ele ressalta que o processo que leva a uma produção imaginal ${ }^{3}$ é tão importante como entender o "produto acabado", ou seja, "o que é uma imagem" tem um peso equivalente ao "como tornou-se imagem". O "como é a genuína comunicação, é a autêntica forma linguística da imagem" (idem, p. 22), explica. Para Belting, uma imagem tem uma via de mão-dupla, ou seja, o homem a vê, ela entra no seu corpo como uma introjeção imagética, será formada a percepção, e então é

3 O termo "imaginal" não deve ser entendido como imaginário, segundo Belting (2014), mas com o ato de "tornar imagem". 
exteriorizada novamente já carregada de significados que a percepção formulou. Por isso ela é simbólica.

O pensador alemão ressalta ainda que, somente na visão antropológica podemos eleger o homem como um "meio", é nele que as imagens se formam e não apenas faz uso dele como inventor de técnicas imagéticas. Nesse sentido, o conceito de imagens internas (endógenas) e externas (exógenas) é muito importante para a compreensão de como a imaginação e as emoções podem influenciar no resultado de uma imagem, uma vez que a imagem endógena tem uma capacidade de processar novas imagens a partir de imagens ancestrais.

Quando Toledo, nos seus cadernos de merda, traz o excremento e o animal, está buscando na ancestralidade uma história de continuidade, como se o passado "sobrevivesse" ali. A noção de sobrevivência, em Warburg, "supõe uma espécie de memória inconsciente, própria da memória coletiva”, de acordo com Kern (2010, p. 16). Verónica Volkow, numa análise das litografias de Toledo de 1964, percebe que ele vai acrescentando elementos que poderiam se repetir de maneira infinita e coesa sem que se saiba onde é o fim, onde é o início: "Seres dispersos, aparentemente ajenos, son enlazados por una arbitraria continuidad, a la que podría de hecho vincularse cualquier cosa; nada, nada, nadie escaparía de la historia" (VOLKOW, 2015, p. 53).

O estudo interdisciplinar de Warburg, no início do século XX, permite articular as experiências individuais de artistas com as tradições culturais. Não postula uma historiografia evolutiva e linear como considerava Kant, por exemplo; mas defende que a arte seja vista como uma interlocução entre mundo antigo e moderno; entre imagem e contextos culturais. Kern (2010) menciona que no estudo sobre a arte florentina, Aby Warburg já associava a pintura de Botticelli com a dança. Para ele, a imagem não tem que ser algo estaque, fechado, mas é associativa e pode se relacionar com outras áreas do conhecimento, tais como a antropologia, a sociologia ou a psicologia, por exemplo. Por isso mesmo, o estudo não se restringe às obras em si, mas ele incluía mapas, cartas, testamentos, mitos, entre outros documentos desprezados anteriormente para um estudo sistematizado. Warburg, para além dos 
conceitos de memória ${ }^{4}$, nos traz, em El ritual de la serpiente, uma rica contribuição sobre o animal também, que dialoga com nossa leitura da obra de Toledo - a equivalência homem-animal. Ele questiona o porquê da crença de que o homem está acima do animal. E afirma: "Observa al antílope que es puro correr, y corre mucho mejor que el hombre, u observa al oso que es la fuerza pura. Los hombres sólo hacen en parte lo que el animal es eternamente" (WARBURG, 2008, p.30). O animal, para Toledo, é um símbolo.

Os símbolos, de acordo com Aby Warburg, têm uma relação estreita com o imaginário, com o fantástico e com o hibridismo de uma civilização pagã e primitiva. Em seu relato, escrito vinte e sete anos depois de viver no Novo México, lemos: "Los pueblos viven entre el mundo de la lógica y el de la magia, y su instrumento de orientación es el símbolo. Entre el hombre salvaje y el hombre racional, se sitúa el hombre de las interconexiones simbólicas" (WARBURG, 2008, p. 27). Warburg exemplifica essas interconexões com as danças e com o uso de máscaras como rituais dos pueblos. A dança dos antílopes coloca em jogo a imitação do animal e as máscaras significam uma apropriação espiritual dos animais. Detalha:

\begin{abstract}
Esta ceremonia no tiene nada de lúdica: para el hombre primitivo, la danza de las máscaras significa, en el proceso de unión con lo extrapersonal, el mayor grado de sometimiento a una entidad extraña. Cuando, por ejemplo, el indio imita los movimientos y las expresiones del animal, no se introduce en el cuerpo de la presa para divertirse, sino para poder apropiarse mágicamente de un elemento de la naturaleza a través de una metamorfosis de su personalidad, algo que no podría obtener sin ampliar y modificar su condición humana (WARBURG, 2008, p. 28).
\end{abstract}

Perceber essas interconexões homem-animal em Toledo é também fazer uma leitura anacrônica de sua obra com os povos primitivos. David Huerta (1993, p. 13) comenta, sobre a obra de Toledo: "hay otros mundos pero están en éste".

Toledo ilustra, inclusive, o livro de Jorge Luis Borges, Zoología fantástica (2013), onde fica claro o hibridismo e sua familiaridade com as narrativas zoológicas borgeanas. O bestiário em questão não privilegia animais comuns como leões ou

4 Wargurg criou o Atlas Mnemosyne, no qual consegue pensar a história por um método comparativo de imagens: "As distintas articulações para estudar as imagens são efetuadas porque elas são consideradas como verdadeiros mediadores culturais, vivas, dinâmicas e que contribuem para dar forma, sentido e existência ao mundo" (KERN, 2010, p. 16). 
elefantes, por exemplo. Elege cruzamentos atípicos, dá margem ao imaginário fantástico com uma fauna totalmente incomum. No prefácio, Carlos Monsiváis pontua: "[...] es un resumen notable de las ideas majestuosas de los antigos, cuando losmonstruos de moda aún no se adquirían en videoshops y jugueterías y todo quedaba al arbitrio del poderío de las visiones interiores" (MONSIVÁIS apud BORGES; TOLEDO, 2013, p. 17).

As imagens escatológicas de Francisco Toledo têm sido pensadas aqui via concepção de Belting e Warburg, na qual o corpo produz essas imagens, sendo a linguagem concebida após o processo endógeno/exógeno. Christoph Wulf (2014), no artigo "Emoção e imaginação: perspectivas da antropologia histórico-cultural" explica que somos sujeitos e objetos de nossas emoções, que não podemos controlá-las e deixar de senti-las, no entanto, não podemos transformar a emoção em objeto de conhecimento porque ela é fluida e as linguagens não são capazes de apreendê-las por completo. Nesse entendimento de imagem endógena, em que ela pode ser transformada também pelas emoções, compreendemos porque os meios só se valem no contexto da imagem e do corpo: cada pessoa tem sua história, seu contexto cultural, suas emoções próprias. Por isso, também Belting nos atenta para a consciência corporal e a diferenciação entre memória e recordação:

As imagens da recordação e da fantasia surgem no nosso corpo como se este fosse um suporte vivo. Como se sabe, esta experiência suscitou a distinção entre memória [Gedächtnis], enquanto arquivo imaginal do próprio corpo, e recordação [Erinnerung], enquanto produção endógena de imagens (BELTING, 2014, p. 24).

É importante ressaltar que as imagens internas e as externas "caminham juntas". As primeiras são próprias do corpo e, as segundas precisam ter passado pela configuração interna para chegar ao nosso olhar. Embora cada uma tenha sua função própria, elas são indissociáveis porque não pode haver dualidade entre espírito e matéria. No caso de uma história de imagens no âmbito coletivo, é preciso cuidado, pois somente as imagens exógenas podem ser pensadas como representação externas, mas nem sempre as endógenas representam o individual: "As nossas imagens interiores nem sempre são de natureza individual, mas, mesmo se forem de origem coletiva, são de tal modo interiorizadas por nós que as temos por genuínas imagens nossas" (BELTING, 2014, p. 33). Aquilo que nos é familiar, coletivo, já 
começa a ser determinante como significação individual, sem que haja uma reflexão sobre a origem dessa imagem que compreendemos como nossa. E a cultura, como também valorizava Warburg, tem um peso grande em nossas percepções: "Apesar de os nossos órgãos sensoriais não terem se modificado, a nossa percepção está sujeita à mudança cultural” (BELTING, 2014, p. 34).

O íntimo e o exterior vão então se complementando: imagens endógenas e exógenas; dentro e fora na plástica tolediana (órgão genital, excrementos, vômito). Nessa perspectiva, Verónica Volkow afirma que poucos artistas contemporâneos representaram tanto a anatomia humana como Francisco Toledo:

[...] sus personajes, si no están expulsando cuerpos u objetos que son sus interiores, viven incorporándose lo que serán sus entrañas, devorándose o insertándose seres que irán a constituirlos. El cuerpo se llena de los entes que atrapa o con los que copula: preñez extraña que lo configura. Es como si con una sintaxis sexual Toledo se explicara el interior del cuerpo, actos eróticos articulan sus partes; de las entrañas surgen seres escenificando historias lúbricas, la carne es una constante invención. Toda vinculación aquí lleva a un devoramiento, se convierte en entraña. Un cuerpo devora a otros cuerpos, pero éstos también entran robándose su identidad, quedándose dentro, investidos de forma y energía particulares, hirviendo de apetitos (VOLKOW, 2015, p. 65-66).

O corpo é representado então pelo de dentro e pelo de fora. $\mathrm{O}$ ato de evacuar e o vômito simbolizam isso. Toledo pinta, em seus cadernos, a merda saindo do homem ou do animal (ou do hibridismo deles) e sendo transformada num novo ser, como se dali já pudéssemos imaginar um "super adubo" que daria vida ao próximo elemento. Para ele, homem e animal são seres integrados — homem-animal —, numa relação de convivência, comunicação e cumplicidade. O ato sexual (ou copulação) também evoca esse entra-e-sai na obra do artista. O órgão genital está sendo mostrado tanto para aludir o sexo, quanto um orifício de saída do excremento.

Quando pesquisamos sobre a merda na antropologia, muitas referências nos levam às discussões sobre a abjeção do ponto de vista do nojo, do repugnante, da interdição; com valiosas análises no terreno do corpo, tais como O tabu do corpo; de José Carlos Rodrigues; Poderes de la perversión, de Julia Kristeva ou Pureza e perigo, de Mary Douglas. 
Embora Julia Kristeva aborde uma perspectiva do nojo como algo simbólico, optamos por seguir pelo caminho das imagens. Nossa análise se enveredou pelas teorias de Aby Warburg e Hans Belting, possibilitando que relações culturais e de memória fossem consideradas. Assim, acreditamos que a obra de Francisco Toledo emerge a merda como um elemento simbólico de uma cultura primitiva. Tal símbolo pode aludir à riqueza, à prosperidade, à igualdade social, à nossa animalidade, ao homem primitivo. Toledo não precisa, necessariamente, pensar em tudo isso durante sua produção artística, mas o seu conhecimento a respeito dos mitos, sua fluência na língua zapoteca, sua erudição poética, artística e filosófica o levam a produzir obras dessa natureza, que são temas inerentes ao seu imaginário. Não há nojo nem distanciamento para se falar de merda. Há uma imaginação cheia de movimentos capazes de exteriorizar emoções que sobrevivem.

\section{Referências}

BAITELLO JR, Norval. O Pensamento Sentado - Sobre glúteos, cadeiras e imagens. São Leopoldo: UNISINOS, 2012.

BAKHTIN, Mikhail. A cultura popular na Idade Média e no Renascimento - O contexto de François Rabelais. Tradução de Yara Frateschi Vieira. São Paulo/ Brasília: Editora Hucitec / UnB, 2008.

BELTING, Hans. "Meio, imagem, corpo". In: BELTING, Hans. Antropologia da Imagem. Lisboa: KKYM + EAUM, 2014, p. 21-116.

BORGES, Jorge Luis; TOLEDO, Francisco. Zoología fantástica. 2. ed. México - DF: Artes de México, 2013.

DIDI-HUBERMAN, Georges. Que emoção! Que emoção? Tradução Cecília Ciscato. São Paulo: Editora 34, 2016.

DOUGLAS, Mary. Pureza e perigo. Lisboa: Edições 70, 1991.

KRISTEVA, Julia. Poderes de la perversión. Buenos Aires: Siglo XXI, 1987.

HUERTA, David. Los cuadernos insomnes de Francisco Toledo. In: INSTITUTO NACIONAL DE BELLAS ARTES. Los cuadernos insomnes de Francisco Toledo. México, 1993.

KERN, Maria Lucia. Imagem, historiografia, memória e tempo, ArtCultura, v. 12, n. 21, 2010.

PERNIOLA, Mario. Desgostos. Tradução de Davi Pessoa Carneiro. Florianópolis: Editora da UFSC, 2010.

RODRIGUES, José Carlos. O tabu do corpo. Rio de Janeiro: Ed. Universidade, 1975.

TOLEDO, Francisco. Libreta de apuntes. Textos de Anne Schumacher y Carlos Monsiváis. México: Galería Arvil, FCE, 2003.

TOLEDO, Francisco. Los cuadernos de la mierda. Mexico - DF: Secretaria de Hacienda y Crédito Público, 2001.

VIGARELLO, Georges. O limpo e o sujo, uma história da higiene corporal. São Paulo: Martíns Fontes, 1996.

VIGARELLO, Georges. Le propre et le sale: I'hygiène du corps depuis le Moyen Age. Paris : Seuil, 1985. 
VILARREAL, Jaime Moreno. Francisco Toledo - El ideograma del insecto. México - DF: Círculo de arte, 1999.

VOLKOW, Verónica. La mordedura de la risa. Un estudio sobre la obra gráfica de Francisco Toledo. Ciudad de Mexico: Fonde de Cultura Económica, 2015.

WARBURG, Aby. El ritual de la serpiente. Traducción de Joaquín Etorena Homaeche. Madrid: Editorial Sexto Piso, 2008.

WULF, Christoph. Emoção e imaginação: perspectivas da antropologia histórico-cultural. In: BAITELLO JR, Norval; WULF, Christoph (Org.). Emoção e imaginação: os sentidos e as imagens em movimento. São Paulo: Estação das Letras e Cores, 2014.

\section{Vanessa Daniele Moraes}

Bacharel e Licenciada em Letras Português pela Universidade Federal de Santa Catarina. Mestre em Literatura pela mesma universidade. Doutoranda em Comunicação na linha de pesquisa "Imagem, som e escrita" pela Universidade de Brasília. Investiga as faces da abjeção nas artes e na Estética.

E-mail: quantasvanessas@gmail.com

Currículo: http://lattes.cnpq.br/8314644813292366

Recebido em 30 de janeiro de 2017 Aceito em 21 de abril de 2017 